\title{
INFESTATION OF WeEd SPECIES IN MONOCROP COFFEe OR INTERCROPPED WITH BANANA, UNDER AGROECOLOGICAL SYSTEM ${ }^{1}$
}

\author{
Infestação de Plantas Daninhas em Café Cultivado Isoladamente ou em Consórcio com \\ Banana, sob Sistema Agroecológico
}

\author{
CONCENÇO, G. ${ }^{2}$, MOTTA, I.S. ${ }^{2}$, CORREIA, I.V.T. ${ }^{3}$, SANTOS, S.A. ${ }^{4}$, MARIANI, A. ${ }^{3}$, MARQUES, \\ R.F. ${ }^{5}$, PALHARINI, W.G. ${ }^{3}$, and ALVES, M.E.S. ${ }^{3}$
}

\begin{abstract}
We aimed with this study to compare weed infestation in coffee under two different cropping managements: conventional coffee grown alone, or intercropped with banana plantation in a year-round basis (late spring, late summer, late fall and late winter). The experiment was installed in 2009 under field conditions at the Escola Municipal Rural Benedita Figueiró de Oliveira, in the city of Ivinhema in the state of Mato Grosso do Sul, Brazil. Assessments of weed occurrence were made three years after employment, on both cropping systems, and density, frequency, dominance and the importance value for each plant species in each system and season were quantified. Plant diversity within each system was estimated by Simpson and Shannon-Weiner indexes. Similarity between cropping systems were also assessed by the binary asymmetric similarity coefficient of Jaccard. Absolute infestation and spontaneous species differed between the two cropping systems in all seasons. Overall species diversity is higher in the monocrop compared with the intercrop, and it is associated in this study with the higher incidence of troublesome species. Areas were similar in terms of weed composition only in the Fall. Shading provided by the banana trees shows to be an efficient culture management aiming to suppress weeds in agro-ecological planting systems.
\end{abstract}

Keywords: weed occurrence, intercrops, phytosociology.

\begin{abstract}
RESUMO - Objetivou-se com este trabalho comparar a infestação de plantas daninhas em café sob dois manejos de cultivo diferentes: café convencional cultivado isoladamente (solteiro) e em consórcio com banana (final da primavera, fim do verão, outono e final do inverno). O experimento foi instalado em 2009, em condições de campo, na Escola Municipal Rural Benedita Figueiró de Oliveira, em Ivinhema, Mato Grosso do Sul, Brasil. Foi avaliada a ocorrência de espécies daninhas três anos após a implantação, em ambos os sistemas de cultivo, sendo quantificada a densidade, frequência, dominância e valor de importância para cada espécie ocorrente. A diversidade de espécies dentro de cada sistema foi estimada pelos indices Simpson e Shannon-Weiner, e os sistemas de cultivo foram ainda comparados pelo coeficiente binário assimétrico de similaridade de Jaccard. A infestação absoluta de espécies espontâneas diferiu entre os dois sistemas de cultivo em todas as estações, $e$ a diversidade das espécies foi maior na monocultura em comparação com o consórcio, mostrando maior incidência de espécies problemáticas. As áreas foram semelhantes em termos de composição de plantas daninhas somente no outono. O sombreamento proporcionado pela bananeira mostrou-se eficiente no manejo cultural na supressão de plantas daninhas em sistemas de plantio agroecológicos.
\end{abstract}

Palavras-chave: ocorrência, consórcio, fitossociologia.

Recebido para publicação em 27.6.2014 e aprovado em 30.6.2014.

2 Embrapa Western Agriculture, Dourados-MS, Brazil, <germani.concenco@embrapa.br>; ${ }^{3}$ University Anhanguera, Dourados-MS, Brazil; ${ }^{4}$ University Unigran, Dourados-MS, Brazil; ${ }^{5}$ Federal University of Grande Dourados, Dourados-MS, Brazil. 


\section{INTRODUCTION}

Coffee (Coffea arabica) originated from Africa, where it evolved as an understory shrub species (Elevitch et al., 2009) adapted to some degree of shading. In several regions, farmers plant coffee under cover crops such as avocado (Persea americana), mango (Mangifera indica), citrus (Citrus spp.) and banana (Musa spp.) (Elevitch et al., 2009; Souza et al., 2010). A cover crop is a crop planted primarily to manage soil fertility, soil quality, water, weeds, pests, diseases, biodiversity and wildlife in an agroecosystem (Lu et al., 2000). Besides shading, these overstory cover crop trees in coffee plantations would also supply additional products for subsistence or income (Elevitch et al., 2009).

Agroecological systems, for not allowing the use of most chemical inputs used in conventional systems - among them, herbicides, widely adopt mechanical and cultural management practices for weed suppression. For the same crop, distinct management systems differ in terms of selection factors imposed to the community of weeds, so that each selects certain species most adapted to that particular environment. Thus, even if there are changes in levels of infestation due to the chosen management, some species may be more difficult to control or will cause greater negative impact on the system than others, either for surviving the adopted management practices, or for appearing in moments other than when the control practices are applied (Silva \& Silva, 2007).

In agroecological systems, weed suppression should be based as mandatory in the use of cover crops (which prevents access to light), the preventive management (avoiding the introduction of propagules from alien species), the use of fast growth cultivars (competitive advantage for the crop), and crop rotation (diversification of management practices). Thus, shading promoted to coffee plantations by overstory tree species would suppress weed occurrence, mainly those with $\mathrm{C}_{4}$ route carbon metabolism, which demand higher light levels than $\mathrm{C}_{3}$ species for their development (Gurevitch et al., 2006). Among the ten most important weed species worldwide, seven are $\mathrm{C}_{4}$ species (Silva \& Silva, 2007).

Understanding not only the level of occurrence, but also the composition of the weedy community, allows for more effective managements in suppressing weeds (Silva \& Silva, 2007). Phytosociological studies provide the estimation of the density of individuals, the frequency of species occurrence and the dominance of certain weed species over others, thus allowing to classify them by their relevance within a given ecosystem, whether natural or agricultural (Barbour et al., 1998).

This present study aimed to compare weed infestation in coffee under two different cropping managements: conventional monocrop coffee, or intercropped with banana plantation, in a year-round basis.

\section{MATERIAL AND METHODS}

The experiment was installed in 2009 under field conditions at the Escola Municipal Rural Benedita Figueiró de Oliveira, in the city of Ivinhema in the state of Mato Grosso do Sul, Brazil (22 22' 03" S, 53 55' 03” W, 420 m asl). Meteorological data registered at the location, from November 2011 to September 2012, is shown in Figure 1. Coffee seedlings were obtained from an officially registered Brazilian production yard, in the city of São Jorge do Patrocínio - PR. Each cropping system in the trial occupied an area of approximately $2,000 \mathrm{~m}^{2}$.

In the agroecological system, coffee trees cv. IAPAR 59 were planted at distances of $3 \mathrm{~m}$ between rows and $2 \mathrm{~m}$ between holes, with two plants per hole, which resulted in final density of 3,334 plants ha ${ }^{-1}$ for both systems (single coffee and coffee banana intercrop). Although this is not an up-to-date plant spacing, it allows the introduction of other species in the intercrop according to the agroecological concepts. In the intercrop, the banana variety Nanicão, interspersed with coffee trees, was planted in a spacing of $3 \mathrm{~m}$ between rows and $4 \mathrm{~m}$ between holes, with three plants per hole, which resulted in a density of 2,500 plants $\mathrm{ha}^{-1}$. In the initial establishment of both cropping systems, sugarcane bagasse was used as mulch ( $3 \mathrm{~kg}$ per plant), to 


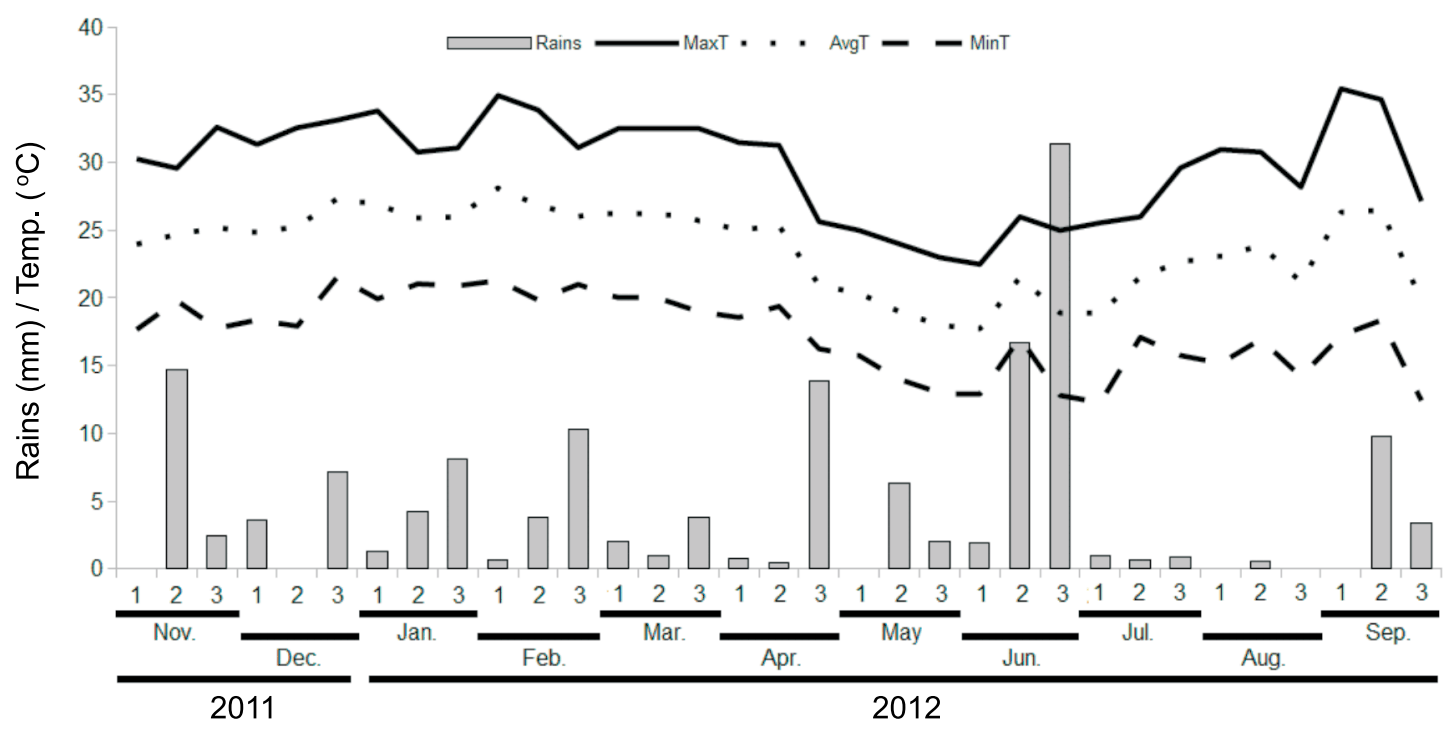

Figure 1 - Meteorological data from November 2011 (first assessment) to September 2012 (last assessment).

maintain soil moisture, reduce the incidence of weed species, as well as to protect soil from erosion.

In the preparation of the area, terracing contours were drawn with tractor towed equipment. Liming and fertilization were carried out according to soil analysis. Fertilization at planting was performed in furrows (40 cm depth) with organic and mineral fertilizers, 40 days before planting. The basic fertilization for coffee consisted of applying at every meter of furrow $20 \mathrm{~kg}$ of organic fertilizer (obtained by composting) brand Organoeste ${ }^{\circledR}$ (obtained from decomposing animal slaughter residues, fruit bagasse, and tree bark, among others) along with $330 \mathrm{~g}$ of thermophosphate $\left(18 \% \mathrm{P}_{2} \mathrm{O}_{5}\right)$ and $60 \mathrm{~g}$ of potassium sulphate $\left(50 \% \mathrm{~K}_{2} \mathrm{O}\right)$ applied at planting. Maintenance fertilization was accomplished with poultry litter at the $1^{\text {st }}$ year with $2 \mathrm{~kg}$ and in the $2^{\text {nd }}$ year with $3 \mathrm{~kg}$ per hill (applied under the canopy projection).

Pests and diseases were kept at acceptable levels with application of phyto protector neem oil 6 to 7 times a year, alternating with application of the biofertilizer "super magro" (Paulus et al., 2000) at 5\% with $100 \mathrm{~L} \mathrm{ha}^{-1}$ of spray solution.

Weeds were controlled by hoeing every 30 days in the rainy season, and every 60 days in the dry season, from the start of experiment in 2009, until September 2011, when hoeing was interrupted only in the areas previously established for the assessment of weed occurrence. From 2009 to 2011 (throughout the experiment) and from 2011 on (outside the area assessed for weeds), hoeing was performed every 30 days during the rainy season, and every 60 days during the dry season, averaging 9-10 hoeings per year. The shading of banana trees on coffee was assessed with septometer AccuPAR (Decagon Devices, Inc.), averaging $60 \%$, which is a little higher than the $40-50 \%$ considered ideal for coffee (Elevitch et al., 2009).

\section{Phytosociological analysis}

Phytosociological characterizations of weeds emerged from soil seed bank were conducted in four moments: November (late Spring), February (late summer), May (late Fall), and August (late Winter), on 16 randomly marked, permanent points in each cropping system, each one with an area of $0.50 \times 0.50 \mathrm{~m}$. In each sampling point, at each assessed season, all seedlings emerged (at least $1 \mathrm{~cm}$ height/length) were identified by botanical species, counted, collected and stored in paper bags by species, and put in the oven with forced air circulation at $65^{\circ} \mathrm{C}$ to constant weight, for posterior determination of dry mass. 
In each area (coffee alone or intercropped with banana), for each species, the density (based on number of individuals), frequency (spatial distribution of the species) and dominance (ability to accumulate mass) were obtained according to Barbour et al. (1998), considered in this study only in relative terms. Based on these three parameters, the importance value of infestation for each species in each area was also determined (Curtis \& McIntosh, 1950). Areas were also intra analyzed for diversity by Simpson (D) and Shannon Weiner (H') diversity indexes (Gurevitch et al., 2006). Subsequently, areas were compared by Jaccard's binary asymmetric similarity coefficient (Barbour et al., 1998).

\section{Statistical analysis}

All analyses were performed in the $R$ statistical environment (R Core Team, 2013), by using commands made available by the following packages: graphics, vegan, Hmisc, cluster and ExpDes. All formulas and procedures, both for area sampling and community description and grouping, followed the concepts stated by Barbour et al. (1998) for synecological analysis.

\section{RESULTS AND DISCUSSION}

\section{Number and dry mass of weeds}

The number of weeds collected differed between treatments according to Fisher's LSD test at 5\% probability for all seasons but Summer (Figure 2). For dry mass, differences were found for all seasons but Winter. In Spring, 28 plants $\mathrm{m}^{2}$ of weed species were found in the intercrop, while for coffee in monocrop, 164 plants $\mathrm{m}^{2}$ were found (Figure 2A). Dry mass was similar to plant number; in the intercrop, only $23 \mathrm{~g} \mathrm{~m}^{2}$ of dry mass were obtained while for coffee grown alone, $354 \mathrm{~g} \mathrm{~m}^{2}$ was attributed to the weedy community (Figure 2A). In percentages, infestation in the intercrop equals to approximately $17 \%$ and $6.5 \%$ of infestation found for coffee in monocrop, respectively in terms of number of seedlings of weed species and dry mass (Figure 2A). For late Summer (Figure 2B), the number of seedlings of plant species in the intercrop equaled to about $64 \%$ of that found in the monocrop; as for dry mass, this difference was greater, infestation in the intercrop was only $6.1 \%$ of that in the monocrop. This difference was greatly reduced in the Fall (Figure 2C), where differences between monocrop and intercrop were only about 35\% for number of plants and 39\% for dry season. In the Winter (Figure 2D) there was a high flux of seedlings emergence of weed species, however with practically no dry mass accumulation.

Probably, the presence of overstory banana highly inhibited the occurrence of infestation when all areas are considered altogether (Figure 2). Two factors are usually associated with the level of weed occurrence in cropping systems: the exudation of compounds with allelopathic activity to soil (Khan et al., 2012), and the direct effect of shading, which results in competition for light in qualitative and quantitative terms (Begna et al., 2002). Banana tree is not known to produce potent allelopathic compounds, but on the other hand its effects on the inhibition of weed occurrence is confirmed (Espindola et al., 2000). When the number of plants of weed species is checked against the dry mass accumulated by them, it is possible to confirm that banana tree shading has affected not only weed germination, but also the growth ability of plants that were able to germinate even under shading (Figure 2).

There was a remarkable contrast between Summer (Figure 2B) and Winter (Figure 2D), where in the former a relatively small number of plants was able to accumulate huge amounts of dry mass (the highest observed throughout the year); and in the latter, a big number of seedlings was found, however with little ability to accumulate dry mass. In the Summer of the Middle-West region of Brazil, high levels of light and soil moisture are usually available, associated to high temperatures. This usually benefits $\mathrm{C}_{4}$ carbon metabolism species, which are able to grow faster (Barbour et al., 1998); following an exaggerated growth rate, weaker plants started to be eliminated by self-thinning (Rivera \& Scrosati, 2008), which resulted in few plants remaining in the area, each with high amounts of dry mass. In the winter, however, plants were able to germinate and emerge, but due to scarce soil moisture 

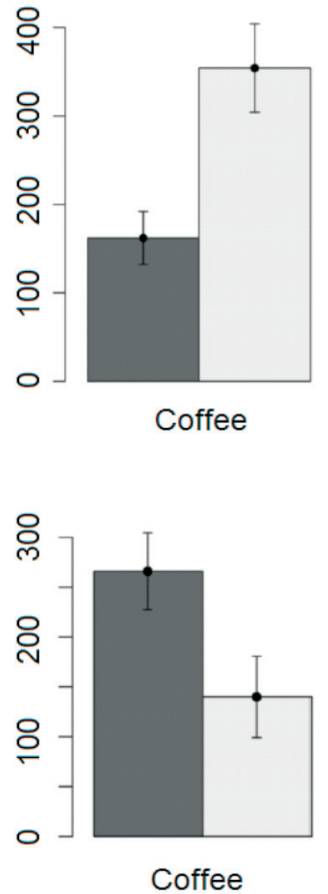

(A)

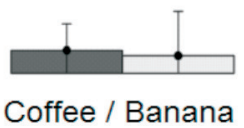

(C)

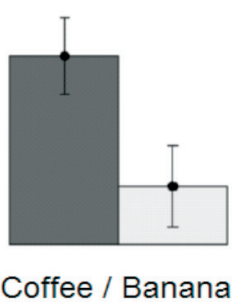

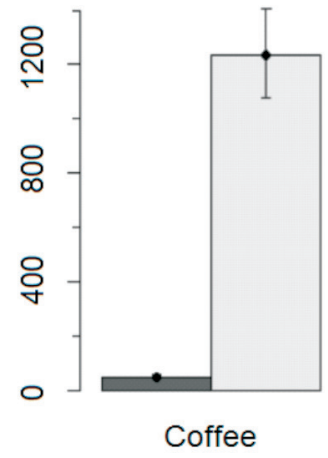

(B)

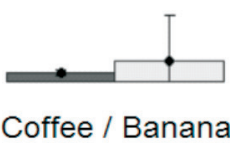

(D)
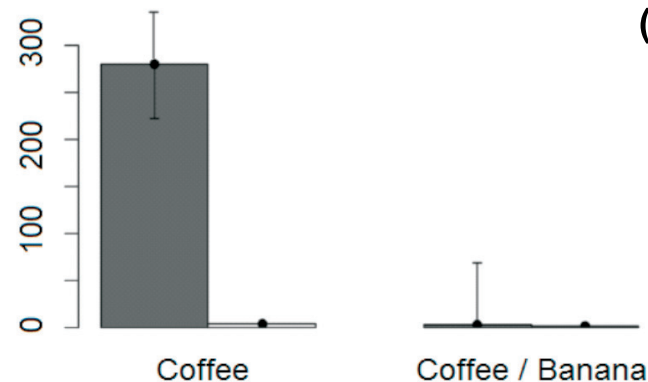

Error bars are presented over columns.

Figure 2 - Number of weed plants

- per square meter) and dry mass of the weedy community $\left(\square-\mathrm{g} \mathrm{m}^{-2}\right)$ as a function of treatments (coffee in monocrop or intercropped with banana), and assessment season ( $\mathrm{A}=$ late Spring; $\mathrm{B}=$ late $\mathrm{Summer}$; $=$ late Fall; $\mathrm{D}=$ late Winter).

and lower environmental temperature, net photosynthesis was probably too low to allow adequate plant growth. In addition, in all seasons but Fall (Figure 2C) great differences were found for infestations in the cropping systems, whereas lower infestation was always noted for the intercrop (Figure 2).

\section{Phytosociology}

The phytosociological analysis was based on the Density, Frequency and Dominance parameters. Density (or for instance abundance) is the number of plants rooted within each quadrat. Frequency is the proportion of total quadrats that contain at least one rooted individual of a given species. A Dominant species of a community is the overstory species that contributes with the most covering to the community (Barbour et al., 1998). The most important weed species is that able to perform greatly in all parameters: it has a relatively numerous offspring, which is widely distributed in the area, and its growth rate is high enough to close its canopy faster, shading and inhibiting seedlings of other weed species (Concenço et al., 2013).

Assessment made in the Spring suggested that in the intercrop, Chamaesyce hirta was solely responsible for $71 \%$ of the importance value (IV) of infestation (Table 1), while Digitaria horizontalis accounted for $21 \%$ of the infestation. C. hirta is highlighted for its high density, frequency and dominance; $D$. horizontalis was also efficient in overdominating Amaranthus hybridus, although it has been dominated by $C$. hirta (Table 1). In coffee grown in monocrop, about $50 \%$ of infestation importance was attributed to $D$. horizontalis, followed far by Richardia brasiliensis and Eleusine indica (Table 1). It is also remarkable the occurrence of three species relatively tolerant to glyphosate under the monocrop, namely $R$. brasiliensis, Commelina benghalensis and Ipomoea purpurea, 
Table 1 - Phytosociological analysis of weed species and its relevance in coffee grown alone or intercropped with banana plantation

\begin{tabular}{|c|c|c|c|c|c|c|c|c|c|c|c|c|c|c|c|c|c|c|c|c|}
\hline \multirow{2}{*}{ Plant Species } & \multicolumn{4}{|c|}{ Late spring } & \multicolumn{4}{|c|}{ Late summer } & \multicolumn{4}{|c|}{ Late fall } & \multicolumn{4}{|c|}{ Late winter } & \multicolumn{4}{|c|}{ Pooled analysis } \\
\hline & $\mathrm{DE}$ & FR & DO & VI & $\mathrm{DE}$ & FR & DO & VI & $\mathrm{DE}$ & FR & DO & VI & $\mathrm{DE}$ & FR & DO & VI & $\mathrm{DE}$ & FR & DO & VI \\
\hline \multicolumn{21}{|c|}{ Coffee Grown Alone } \\
\hline $\begin{array}{l}\text { Amaranthus } \\
\text { hybridus }\end{array}$ & & & & & 2.13 & 5.56 & 2.88 & 3.52 & & & & & & & & & 0.53 & 1.39 & 0.72 & 0.88 \\
\hline $\begin{array}{l}\text { Brachiaria } \\
\text { plantaginea }\end{array}$ & & & & & & & & & & & & & 91.43 & 50.00 & 84.75 & 75.39 & 22.86 & 12.50 & 21.19 & 18.85 \\
\hline $\begin{array}{l}\text { Cenchrus } \\
\text { echinatus }\end{array}$ & & & & & 2.13 & 5.56 & 1.42 & 3.04 & & & & & 0.36 & 16.67 & 3.75 & 6.93 & 0.62 & 5.56 & 1.29 & 2.49 \\
\hline $\begin{array}{l}\text { Chamaesyce } \\
\text { hirta }\end{array}$ & 1.23 & 8.33 & 0.47 & 3.34 & & & & & 0.38 & 5.26 & 0.01 & 1.88 & & & & & 0.40 & 3.40 & 0.12 & 1.31 \\
\hline $\begin{array}{l}\text { Commelina } \\
\text { benghalensis }\end{array}$ & 1.23 & 8.33 & 0.35 & 3.30 & 6.38 & 11.11 & 0.29 & 5.93 & 0.38 & 5.26 & 0.13 & 1.92 & & & & & 2.00 & 6.18 & 0.19 & 2.79 \\
\hline $\begin{array}{l}\text { Conyza } \\
\text { canadensis }\end{array}$ & & & & & & & & & 0.75 & 10.53 & 0.19 & 3.82 & & & & & 0.19 & 2.63 & 0.05 & 0.96 \\
\hline $\begin{array}{l}\text { Cyperus } \\
\text { difformis }\end{array}$ & 19.75 & 8.33 & 0.18 & 9.42 & 25.53 & 11.12 & 0.60 & 12.42 & 6.77 & 5.26 & 1.11 & 4.38 & 6.79 & 16.67 & 5.75 & 9.74 & 14.71 & 10.35 & 1.91 & 8.99 \\
\hline $\begin{array}{l}\text { Digitaria } \\
\text { horizontalis }\end{array}$ & 46.91 & 16.67 & 71.49 & 45.02 & 29.79 & 22.22 & 58.88 & 36.96 & 36.09 & 21.05 & 72.68 & 43.27 & & & & & 28.20 & 14.99 & 50.76 & 31.31 \\
\hline Eleusine indica & 2.47 & 12.5 & 15.28 & 10.08 & 12.77 & 11.11 & 32.64 & 18.84 & 6.39 & 10.53 & 4.16 & 7.03 & & & & & 5.41 & 8.54 & 13.02 & 8.99 \\
\hline Emilia fosbergii & & & & & & & & & 0.38 & 5.26 & 4.59 & 3.41 & & & & & 0.10 & 1.32 & 1.15 & 0.85 \\
\hline $\begin{array}{l}\text { Gnaphalium } \\
\text { coarctatum }\end{array}$ & & & & & & & & & 40.98 & 21.05 & 14.43 & 25.49 & & & & & 10.25 & 5.26 & 3.61 & 6.37 \\
\hline $\begin{array}{l}\text { Ipomoea } \\
\text { purpurea }\end{array}$ & 0.62 & 4.17 & 0.07 & 1.62 & & & & & & & & & & & & & 0.16 & 1.04 & 0.02 & 0.41 \\
\hline $\begin{array}{l}\text { Portulaca } \\
\text { oleracea }\end{array}$ & 3.70 & 8.33 & 0.37 & 4.14 & & & & & & & & & & & & & 0.93 & 2.08 & 0.09 & 1.04 \\
\hline $\begin{array}{l}\text { Richardia } \\
\text { brasiliensis }\end{array}$ & 19.75 & 16.67 & 11.73 & 16.05 & 4.26 & 5.56 & 0.11 & 3.31 & 7.89 & 15.79 & 2.71 & 8.80 & 1.43 & 16.67 & 5.75 & 7.95 & 8.33 & 13.67 & 5.08 & 9.03 \\
\hline Sida cordifolia & & & & & 6.38 & 11.11 & 1.26 & 6.25 & & & & & & & & & 1.60 & 2.78 & 0.32 & 1.56 \\
\hline Sida rhombifolia & 3.70 & 12.5 & 0.05 & 5.42 & 10.64 & 16.67 & 1.91 & 9.74 & & & & & & & & & 3.59 & 7.29 & 0.49 & 3.79 \\
\hline \begin{tabular}{|l} 
Solanum \\
sisymbrifolium
\end{tabular} & 0.62 & 4.17 & 0.03 & 1.60 & & & & & & & & & & & & & 0.16 & 1.04 & 0.01 & 0.40 \\
\hline \multicolumn{21}{|c|}{ Coffee Grown Under Banana Plantation } \\
\hline $\begin{array}{l}\text { Amaranthus } \\
\text { hybridus }\end{array}$ & 3.85 & 16.67 & 0.09 & 6.87 & & & & & & & & & & & & & 0.96 & 4.17 & 0.02 & 1.72 \\
\hline $\begin{array}{l}\text { Brachiaria } \\
\text { plantaginea }\end{array}$ & & & & & & & & & & & & & 33.33 & 33.33 & 90.91 & 52.52 & 8.33 & 8.33 & 22.73 & 13.13 \\
\hline $\begin{array}{l}\text { Chamaesyce } \\
\text { hirta }\end{array}$ & 80.77 & 66.67 & 68.00 & 71.82 & 90.00 & 50.00 & 58.72 & 66.24 & & & & & & & & & 42.69 & 29.17 & 31.68 & 34.52 \\
\hline $\begin{array}{l}\text { Conyza } \\
\text { canadensis }\end{array}$ & & & & & & & & & 1.59 & 14.29 & 1.49 & 5.79 & & & & & 0.4 & 3.57 & 0.37 & 1.45 \\
\hline $\begin{array}{l}\text { Digitaria } \\
\text { horizontalis }\end{array}$ & 15.38 & 16.67 & 31.91 & 21.32 & 6.67 & 25.00 & 41.00 & 24.22 & & & & & & & & & 5.51 & 10.42 & 18.23 & 11.39 \\
\hline Emilia fosbergii & & & & & & & & & 0.53 & 14.29 & 1.71 & 5.51 & & & & & 0.13 & 3.57 & 0.43 & 1.38 \\
\hline $\begin{array}{l}\text { Gnaphalium } \\
\text { coarctatum }\end{array}$ & & & & & & & & & 96.83 & 57.14 & 96.45 & \begin{tabular}{|l|l} 
& 83.47
\end{tabular} & 66.67 & 66.67 & 9.09 & 47.48 & 40.88 & 30.95 & 26.39 & 32.74 \\
\hline $\begin{array}{l}\text { Leptochloa } \\
\text { filiformis }\end{array}$ & & & & & & & & & 1.06 & 14.29 & 0.34 & 5.23 & & & & & 0.27 & 3.57 & 0.09 & 1.31 \\
\hline $\begin{array}{l}\text { Panicum } \\
\text { maximum }\end{array}$ & & & & & 3.33 & 25.00 & 0.28 & 9.54 & & & & & & & & & 0.83 & 6.25 & 0.07 & 2.39 \\
\hline
\end{tabular}

$\mathrm{DE}=$ relative density $(\%) ; \mathrm{FR}=$ relative frequency $(\%) ; \mathrm{DO}=$ relative dominance $(\%) ; \mathrm{VI}=$ importance value $(\%)$ as average of the previous parameters. Pooled analysis obtained from year-round combined data. 
which were absent from the intercrop. These species may be also hardly controlled by mechanical and physical methods in agroecological cropping systems (Silva \& Silva, 2007).

The summer assessment highlighted the necessary care to be taken with $\mathrm{C}_{4}$ species under high temperature, sunlight and moisture availability (Table 1). While in the intercrop (lower light availability) 66\% of infestation importance was attributed to C. hirta, in the monocrop, grasses were responsible for $45 \%, 39 \%$ and $93 \%$ of the density, frequency and dominance, respectively, depicting its high ability to accumulate dry mass and dominate other plant species. As a result, $59 \%$ of the overall infestation importance in the Summer, in the monocrop, was attributed to grass weed species (Table 1).

In the Fall, grass weed species were also important and $D$. horizontalis was still responsible for $43 \%$ of the Importance Value, but at this season $\mathrm{C}_{3}$ plants more adapted to cooler environments like Gnaphalium coarctatum $(25 \%$ IV) started to appear. This species was also the most important weed in the intercrop, accounting for $83 \%$ of the Importance Value, being D. horizontalis absent from the intercrop in Fall (Table 1). $D$. horizontalis is a widely distributed weed species, occurring in several crops (Silva \& Silva, 2007). One of its particularities, however, is the demand for light in order to start the germination process (Mondo et al., 2010); thus, the shaded environment in the intercrop would greatly contribute to a lower emergence of this species.

In Winter, just a few species were able to germinate due to low temperatures and rare rains in early April and early May (Figure 1). In the monocrop, only four species were found, while only two were observed in the intercrop. Although $D$. horizontalis has completely disappeared from both areas, Brachiaria plantaginea was solely responsible for $75 \%$ and $52 \%$ of the Importance Value, respectively for the monocrop and intercrop systems; and G. coarctatum was also responsible for $47 \%$ of the Importance Value in the shaded, intercrop environment (Table 1). B. plantaginea occurs as a weed species in coffee plantations in
Brazil (Moreira et al., 2013), demanding high light intensities for its emergence and development (Silva \& Silva, 2007; Mondo et al., 2010).

The year-round pooled phytosociological analysis showed $D$. horizontalis, $B$. plantaginea, $R$. brasiliensis and $E$. indica, with Importance Values of $31 \%, 19 \%, 9 \%$ and $9 \%$ respectively, as the most important weed species in the monocrop; for the intercrop, C. hirta, G. coarctatum, B. plantaginea and D. horizontalis, with Importance Values of 34\%, $32 \%, 13 \%$ and $11 \%$ respectively, were the most important weed species (Table 1). In the monocrop $D$. horizontalis is highlighted for its high dominance $(50.76 \%)$, able to accumulate more than half the dry mass of the weedy community while leaving the other half to be shared among the other 16 weed species found (Table 1). In the intercrop, C. hirta and G. coarctatum were highlighted for their density, both species accounted for $83.57 \%$ of the number of plants found in this cropping system (Table 1).

\section{Diversity}

A diversity index is a measure intended to understand the variety of individuals of a given population, thus allowing inferences about a particular plant community in terms of both the number of species found and the balance in the number of individuals per species (Barbour et al., 1998). Simpson's index considers the density of species in the sample while being less sensitive to species richness (Simpson, 1949; Barbour et al., 1998). Shannon-Weiner's H', in contrast, is more sensitive to rare species.

In the Spring, Simpson indicated that the diversity of weed species in the intercrop amounted $54.3 \%$ of that observed in the single coffee; while Shannon-Weiner indicated ratio of $49.3 \%$. Taking both indexes into account, it can be inferred that the diversity observed in the intercrop amounts to approximately 50\% of that found in the single cultivation in the Spring (Table 2). Similarly, in the Summer and in the Fall, higher diversity coefficients (both for $\mathrm{D}$ and $\mathrm{H}^{\prime}$ ) were observed in the monocrop, and, in general terms, diversity was lower in the Fall compared to Spring and Summer (Table 2). 
In the Winter, as opposed to the other seasons, diversity was greater in the intercrop (Table 2). As diversity is estimated through Density data (Barbour et al., 1998), it is possible to infer that diversity was lower in the monocrop because a single species (B. plantaginea) was the solely responsible for $91.43 \%$ of the total number of individuals (Density) while sharing the remaining $8.57 \%$ of the individuals among the other three species (Table 1). In the intercrop, although only two species were observed, their occurrence was more balanced, thus accounting for a more diversified environment (Table 1). The year-round pooled analysis showed that diversity in the monocrop area was about twice the observed in the intercrop.

Although Stohlgren (2007) reports that low productivity (high stress) areas usually present low diversity, this is also true for very productive sites, as a result of competitive exclusion (Barbour et al., 1998). This helps to explain why stressed areas usually increase their diversity as they are recovered from stress, thus highlighting the importance of diversity indexes for inferences in long-term field trials.

In the coffee/Grevillea robusta intercrop, the presence of trees reduced density and frequency of weed species and increased diversity in the area (Silva et al., 2006). In this study, however, both areas were frequently submitted to a strong selection factor (hoeing), which interfered and imbalanced the natural occurrence of plant species. As diversity is essentially species richness weighted by species evenness (or equitability) (Barbour et al., 1998), we may state a hypothesis that the lower diversity observed in the intercrop was overweighted by its essentially low species richness (number of species), which probably also interfered in its results for species evenness. Ricci et al. (2010) did not find differences in weed species richness and diversity in coffee plantations intercropped with Gliricidia sepium. Weeds diversity in coffee intercropping systems, thus, probably depends more on management practices applied for weed control than in tree species intercropped with coffee.

\section{Similarity}

The binary asymmetric similarity coefficient of Jaccard $(\mathrm{J})$ considers areas as being equal when they share a proportion of plant species, with $\mathrm{J} \geq 25 \%$ (Mueller-Dombois \& Ellenberg, 1974). In all seasons but Fall J was lower than $25 \%$, and the monocrop and intercrop were considered distinct in terms of weed species composition (Barbour et al., 1998). In Fall, however, $\mathrm{J}=30 \%$ because those species which were more adapted to summer but still tolerant at some degree to the cool and dry Winter climate, for instance, $D$. horizontalis were still present; on the other hand, species more adapted to winter, such as $G$. coarctatum, had already started to appear in the trial (Table 1). Of the four species observed in the intercrop in the Fall, three were also present in the monocrop in that same season (Table 1).

Gomes et al. (2010) found no similarity by the Sørensen's index between infestation composition in two areas of banana plantation grown on distinct soil types. The authors remark that the weed species with higher importance value are those less affected by the weed management practice applied. Thus, this present study brings the hypothesis that weed species favored by hoeing (supposing residues are not removed from field), could become important for intercrop, once no herbicide is allowed in agroecological planting systems. In addition, the same authors

Table 2 - Diversity coefficients of Simpson (D) and Shannon-Weiner (H') as a function of season and planting system

\begin{tabular}{|l|c|c|c|c|c|c|c|c|c|c|c|}
\hline \multicolumn{1}{|c|}{ Cropping } & \multicolumn{2}{c|}{ Late spring } & \multicolumn{2}{c|}{ Late summer } & \multicolumn{2}{c|}{ Late fall } & \multicolumn{2}{c|}{ Late winter } & \multicolumn{2}{c|}{ Pooled analysis } \\
\hline System & $\mathrm{D}$ & $\mathrm{H}^{\prime}$ & $\mathrm{D}$ & $\mathrm{H}$ & $\mathrm{D}$ & $\mathrm{H}^{\prime}$ & $\mathrm{D}$ & $\mathrm{H}^{\prime}$ & $\mathrm{D}$ & $\mathrm{H}^{\prime}$ \\
\hline Coffee & 0.70 & 2.17 & 0.83 & 2.00 & 0.69 & 1.39 & 0.17 & 0.37 & 0.6 & 1.48 \\
\hline Coffee-Banana & 0.38 & 1.07 & 0.18 & 0.39 & 0.06 & 0.17 & 0.44 & 0.64 & 0.27 & 0.57 \\
\hline
\end{tabular}


Table 3 - Similarity coefficient of Jaccard (J) between cropping systems (coffee grown alone or intercropped with banana plantation) as a function of season

\begin{tabular}{|l|c|}
\hline \multicolumn{1}{|c|}{ Season } & Similarity (\%) \\
\hline Late Spring & $16.7^{\mathrm{ns}}$ \\
\hline Late Summer & $8.30^{\mathrm{ns}}$ \\
\hline Late Fall & $30.0^{*}$ \\
\hline Late Winter & $17.0^{\mathrm{ns}}$ \\
\hline Pooled Analysis & $18.0^{\mathrm{ns}}$ \\
\hline
\end{tabular}

${ }^{\text {ns }}$ not significant difference; * significant difference according to Mueller-Dombois \& Ellenberg (1974).

found that $D$. horizontalis is usually not a troublesome weed in banana plantations, being classified by importance as $14^{\text {th }}$ between 15 species found in banana plantations established in drained lowlands. Thus, in the coffee/banana intercrop, this species would likely reduce its frequency to levels where it would not be a relevant weed species anymore.

In summary, weed species composition differ depending on the coffee cropping system - monocrop or intercropped with banana plantation, and the most troublesome weed species were predominant at the monocrop; the level of weed occurrence also differed between systems, with the largest absolute infestation found in the monocrop. Species diversity is greater in the monocrop, and it is related in this study to the higher incidence of troublesome species; coffee planting systems, in monocrop or intercropped with banana plantation, differ in the similarity of occurrence of weedy species. Shading provided by banana trees shows to be an efficient cultural management aiming to suppress weeds in agroecological planting systems.

\section{LITERATURE CITED}

BARBOUR, M. G. et al. Terrestrial plant ecology. Menlo Park: Benjamin/Cummings, 1998. 688 p.

BEGNA, S. H. et al. Decoupling of light intensity effects on the growth and development of $\mathrm{C} 3$ and $\mathrm{C} 4$ weed species through sucrose supplementation. J. Exper. Bot., v. 53, n. 376, p. 1935-1940, 2002.
CONCENÇO, G. et al. Phytosociological surveys: tools for weed science? Planta Daninha, v. 31, n. 2, p. 469-482, 2013.

CURTIS, J. T.; MCINTOSH, R. P. The interrelations of certain analytic and synthetic phytosociological characters. Ecology, v. 31, n. 3, p. 434-455, 1950.

ELEVITCH, C. R. et al. Shade-grown coffee in Hawai'i: results of a twelve farm study in Kona. Holualoa: Permanent Agriculture Resources, 2009. 22 p.

ESPINDOLA, J. A. A., et al. Potencial alelopático e controle de plantas invasoras por leguminosas herbáceas perenes consorciadas com bananeira. Seropédica: Embrapa Agrobiologia, 2000. 8 p. (Comunicado Técnico, 47).

GOMES, G. L. G. C. et al. Cadastramento fitossociológico de plantas daninhas na bananicultura. Planta Daninha, v. 28, n. 1, p. 61-68, 2010.

GUREVITCH, J. et al. The ecology of plants. Sunderland: Sinauer. 2006. 574 p.

KHAN, N. et al. Assessment of allelopathic effects of parthenium (Parthenium hysterophorus L.) plant parts on seed germination and seedling growth of wheat (Triticum aestivum L.) cultivars. Pak. J. Weed Sci. Res., v. 18, n. 1, p. 39-50, 2012.

LU, Y. C. et al. Cover crops in sustainable food production. Food Rev. Inter., v. 16, n. 2, p. 121-157, 2000.

MONDO, V. H. V. et al. Efeitos da luz e temperatura na germinação de sementes de quatro espécies de plantas daninhas do gênero Digitaria. R. Bras. Sem., v. 32, n. 1, p. 131-137, 2010.

MOREIRA, G. M. et al. Fitossociologia de plantas daninhas do cafezal consorciado com leguminosas. Planta Daninha, v. 31, n. 2, p. 329-340, 2013.

MUELLER-DOMBOIS, D.; ELLENBERG, H. Aims and methods of vegetation ecology. New York: John Wiley \& Sons, 1974. $547 \mathrm{p}$.

PAULUS, G. et al. Agroecologia aplicada: práticas e métodos para uma agricultura de base ecológica. 2.ed. Porto Alegre: EMATER/RS, 2000. 86 p.

R DEVELOPMENT CORE TEAM. R: A language and environment for statistical computing. Vienna: R Foundation for Statistical Computing, 2012. Available at: $<$ http:// www.R-project.org/>. Accessed in: 2 jan. 2012.

RICCI, M. S. F. et al. Produção de biomassa e acúmulo de nutrientes pela vegetação espontânea em cultivo de café orgânico. Coffee Sci., v. 5, n. 1, p. 17-27, 2010.

Planta Daninha, Viçosa-MG, v. 32, n. 4, p. 665-674, 2014 
RIVERA, M.; SCROSATI, R. Self-thinning and size inequality dynamics in a clonal seaweed, Sargassum Lapazeanum, Phaeophyceae. J. Phycol., v. 44, n. 1, p. 45-49, 2008.

SILVA, S. O. et al. Diversidade e frequência de plantas daninhas em associação entre cafeeiros e grevíleas.

Coffee Sci., v. 1, n. 2, p. 126-143, 2006.

SILVA, A. A.; SILVA, J. F. Tópicos em manejo de plantas daninhas. Viçosa, MG: Universidade Federal de Viçosa, 2007. 367 p.
SIMPSON, E. H. Measurement of diversity. Nature, v. 163, p. $688,1949$.

SOUZA, H. N. et al. Selection of native trees for intercropping with coffee in the Atlantic Rainforest Biome. Agrofor. Syst., v. 80, n. 1, p. 1-16, 2010.

STOHLGREN, T. J. Measuring plant diversity: lessons from the field. - New York: Oxford University Press, 2007. $390 \mathrm{p}$. 